Meta

Journal des traducteurs

Translators' Journal

\title{
Stretching Language
}

\section{Eugene A. Nida}

Volume 32, numéro 1, mars 1987

La traduction biblique

Bible Translation

URI : https://id.erudit.org/iderudit/003733ar

DOI : https://doi.org/10.7202/003733ar

Aller au sommaire du numéro

Éditeur(s)

Les Presses de l'Université de Montréal

ISSN

0026-0452 (imprimé)

1492-1421 (numérique)

Découvrir la revue

\section{Citer cet article}

Nida, E. A. (1987). Stretching Language. Meta, 32(1), 42-45.

https://doi.org/10.7202/003733ar

Ce document est protégé par la loi sur le droit d'auteur. L'utilisation des services d'Érudit (y compris la reproduction) est assujettie à sa politique d'utilisation que vous pouvez consulter en ligne.

https://apropos.erudit.org/fr/usagers/politique-dutilisation/
Cet article est diffusé et préservé par Érudit.

Érudit est un consortium interuniversitaire sans but lucratif composé de l’Université de Montréal, l'Université Laval et l'Université du Québec à Montréal. Il a pour mission la promotion et la valorisation de la recherche. https://www.erudit.org/fr/ 


\section{STRETCHING LANGUAGE}

EUGENE A. NIDA

United Bible Societies, New York, USA

For the translator of primary religious texts (early texts of a believing community), probably the most difficult problems exist because the language of such texts is "stretched", not only lexically, in that words are used in extended areas of meaning, but also rhetorically, as the structures and processes reflect the enthusiasm and exuberance of personal experience and kerygmatic motivation.

The stretching of language is particularly evident in such New Testament expressions as "in Christ", "in the heavenlies", "the first-born of creation", and "saved by the blood". Rhetorical exuberance is well illustrated by Colossians 1.9-23, which contains 285 words in Greek but is organized into only threee sentences, in which attributives are piled one upon another. One can only conclude that Paul was so full of his subject and so anxious to include everything that both the meanings of the words and patterns for putting such words together are seriously stretched.

For the early Christian community the relations between the concepts no doubt seemed abundantly clear. But for others, and particularly for people today, there are serious obscurities and ambiguities. Such features are, however, typical of primary religious language in which little or no attention is paid to inconsistencies and even paradoxes. More often than not the texts produced by a new religious movement follow a discourse structure based primarily upon "stream of consciousness", which has its own logic but which does not correspond to the more carefully thought out religious texts of later developments within such religious movements.

For translators, it is extremely important to examine carefully the nature of primary religious language. The extended meanings of words should not come as a surprise, for the religious enthusiasm associated with new religious experience finds it extremely difficult to fit such experience into traditional verbal expressions. The new experience threatens to burst the old, but since there are no new lexical wineskins, the old ones simply have to be stretched. Such extensions of meaning are inevitable in view of the presumed supernatural experiences. When there are no readily available perceptual models to explain the impact of the divine upon the human, one must expect varying degrees of extended and figurative usage in language.

Primary religious language is generally kerygmatic in motivation; that is to say, people wish to witness to this new experience, and it seems so overwhelmingly real and vital that there is no reason for a defensive approach. Accordingly, people prefer to make declarations rather than to offer logical explanations. Experience has priority over history, and divine revelation seems far more relevant than logical assessment. It is no wonder, therefore, that primary religious language is both optimistic and overflowing, and often characterized by hyperboles, ellipses, and distinct in-group expressions.

Secondary religious language, so typical of the second and third generation in a religious movement, begins after some of the initial enthusiasm has died down, and people begin to analyze and evaluate their earlier religious experiences and the ways in which these experiences have been committed to writing. Much of the specialized vocabulary is retained, but the discourse structures are far more systematic and the content more explanatory. Attempts are made to reconcile differences and inconsistencies

Meta, XXXII, 1, 1987 
and to show the relevance of the paradoxes. The approach is generally more impersonal and cautious, with greater precision paid to the use of language and more attention given to logical relations.

The lexical expansions found in Colossians 1.9-23 are typical of the primary religious language in much of the Greek New Testament. There are, of course, various degrees of extension in meaning : some are relatively conventional and others quite novel. In the following list the more or less literal correspondence of the Greek text is given first. This is followed by an identification of the verse number and then an indication of the meaning :

1. filled with knowledge, v.9, i.e., to have complete knowledge ;

2. to walk worthy of the Lord, v. 10, i.e., to live in a manner worthy of the Lord ;

3. to bear fruit, v.10, i.e. to produce acceptable results ;

4. holy ones (traditionally rendered "saints"), v.12, i.e., the people of God;

5. in the light, v.12, i.e., the moral and spiritual realm;

6. power of darkness, v.13, i.e., control by evil forces ;

7. kingdom of the Son of his love, v.13, i.e., realm or rule of his dear Son.

8. image of God, v.15, i.e., the true likeness of God;

9. firstborn of all creation, v.15 i.e., preeminence over all creation;

10. head of the body, the church, v.18, i.e., preeminence and control over the believing community, likened to a body ;

11. firstborn from the dead, v.18, i.e., the first to arise from the dead, and not to later die ;

12. all the fullness, v.19, i.e., the complete nature (of God);

13. making peace, v. 20 , i.e., to eliminate the basis for hostility ;

14. the blood of his cross, v.20, i.e, his death on the cross;

15. enemies, v. 21 , i.e., opposed or hostile (to God);

16. founded, v.23, i.e., well established;

17. under heaven, v. 23 , i.e., on earth ;

18. servant (of the gospel), v.23, i.e., one who preaches (the gospel).

People who were accustomed to Paul's writing and teaching would have had little or no difficulty with most of the expressions occurring in Colossians 1.9-23, but some terms provided real difficulty even for the scholars of the early church. For example, in verse 15 the phrase "firstborn of all creation" became a phrase at the center of the Arian controversy, for this would seem to imply that Jesus was created rather than "eternally generated of the Father". Early theologians insisted, however, that "firstborn" did not mean "first created". Moreover, they insisted that "firstborn" referred not to birth, but to status and preeminence. This is clearly the case in verse 18 , where "firstborn" has nothing to do with birth.

With so many specialized meanings of words, a number of obscurities and ambiguities are inevitable. For example, in verse 20 there is a reference to "those in the heavens", but it is difficult to know whether this is a specific reference to the various thrones, powers, and authorities in verse 16 , or everything which might exist in heaven itself. One must accordingly try to determine precisely what kind of reconciliation would be necessary.

In verse $18 \mathrm{~J}$ esus is referred to by a term traditionally translated "beginning", and there is no indication in the context as to what is involved in such a "beginning". The context would seem to link this to the church, but the Greek term can mean "source", "origin", and "first principle". There certainly may even be a cosmic significance to this term, since the plural of the same term is used in verse 16 in referring to certain supernatural powers. 
One obvious obscurity occurs in the Greek term normally translated "spiritual", which is linked with wisdom and understanding. But is this something which is given by the Spirit of God, or is it something associated simply with the spirits of people ? Or does it perhaps refer to the spiritual experience of the believing community?

Throughout the writings of Paul there is frequent use of the Greek preposition en, used extensively in the phrase "in Christ". This has been interpreted by some scholars as always meaning "in union with Christ", but in some contexts it seems to be clearly a marker of agency ; in other words, "by means of Christ". Does Paul actually make a difference in the meaning of the phrase "in him" in verse 16 and the phrase "through him" later in the same verse, in which both phrases are related to the verb "to create" ? A number of translations render both phrases in exactly the same way, namely, "through him", but a few translations render both expressions as "by him", and still other translations make a distinction, rendering the first phrase as "in him" and the second as "through him". But to say that all things in heaven and upon the earth were created "in him" does not make much sense.

The rhetorical exuberance of primary religious language is readily illustrated by a number of phrases in this same passage, for example, "knowledge of his will in all wisdom and spiritual understanding" (v. 9), "empowered with all power" (v. 11), "powers, lords, rulers, and authorities" (v. 16), "holy, faultless, and blameless" (v. 22), "founded, firm, and unmoved" (v. 23), and "body of his flesh" (v. 22).

One aspect of this rhetorical exuberance is a failure to pay close attention to various relations. Much is included, but often the relations are not specified. For example, in verse 10 there is a phrase meaning "for all pleasing", but there is no specific indication as to precisely who is to be pleased. Likewise, in verse 19 the phrase "all the fullness" must refer to the nature of God as found in Christ, but the relation is not made specific. In verse 10, it is not at all clear as to the relation between "walking worthy of the Lord" and "bearing fruit and increasing in the knowledge of God". Is the latter to be understood as result or as purpose? In verse 14, the expression "the forgiveness of sins" is in apposition with "redemption". But is one to understand that redemption consists simply in the forgiveness of sins ? Or is the forgiveness of sins merely one of the results of being redeemed ? In verse 23, the phrase "the hope of the Gospel" does not indicate whether the hope is derived from the Good News of whether the hope is the Good News. There is considerable scholarly difference of opinion as to how to relate the phrase "in all good works" in verse 10 and, similarly, how to treat the phrase "with joy" in verse 11 .

In view of the lexical and rhetorical features of a passage such as Colossians 1.9-23, it is no wonder that numerous commentaries have been written about the problems in this type of primary religious language. Translators will find plenty of differences of opinion as to the meanings of words and the relations of ideas. But the translator's task should not be to turn such primary religious language into secondary religious language, that is to say, to take something which is vibrant and alive and to turn it into a kind of textbook on theology. If a translator is concerned only with divulging the socalled meaning of the text, he or she may very well miss its even greater significance, namely, its dynamic character. Some translators have made the Epistles of Paul into something resembling a targum, that is to say, a combination of translation and commentary. As a result, much of the enthusiasm lying behind this text is lost and readers fail to sense how early readers of this Epistle must have reacted to it.

The translation in English which seems to come closest to this dynamic exuberance in the Pauline Epistles is J.B. Phillips' rendering. There are certain additional phrases which some persons may criticize, because they do not match specific lexical features in the Greek text. But Phillips has captured the tone, and the reader can sense 
more of what early readers must have experienced as they read this remarkable letter in which Paul's knowledge and experience overflow in rhetorical enthusiasm about the nature and ministry of Christ and the need to proclaim this Good News. Compare, for example, Colossians 1.11-14 in the Revised Standard Version and in Phillips' Letters to Young Churches.

\section{Revised Standard Version}

May you be strengthened with all power, according to his glorious might, for all endurance and patience with joy, giving thanks to the Father, who has qualified us to share in the inheritance of the saints in light. He has delivered us from the dominion of darkness and transferred us to the kingdom of his beloved Son, in whom we have redemption, the forgiveness of sins.

\section{Letters to Young Churches}

As you live this new life, we pray that you will be strengthened from God's boundless resources, so that you will find yourselves able to pass through any experience and endure it with courage. You will even be able to thank God in the midst of pain and distress because you are privileged to share the lot of those who are living in the light. For we must never forget that He rescued us from the power of darkness, and re-established us in the Kingdom of His beloved Son, that is, in the Kingdom of Light. For it is by the Son alone that we have been redeemed and have had our sins forgiven. 